\title{
INFLUENCE OF PLANTING METHOD AND NITROGEN DOSE ON GROWTH AND YIELD OF QUINOA (Chenopodium quinoa Willd.)
}

\author{
P.K. Biswas ${ }^{1}$, K. Fatema ${ }^{2}$ and A. Rahman ${ }^{3}$ \\ ${ }^{1}$ Prof., ${ }^{3}$ Assoc. Prof., Department of Agronomy, SAU \\ ${ }^{2} \mathrm{MS}$ student, Department of Entomology, SAU \\ Dhaka-1207, Bangladesh \\ Corresponding E-mail: parimalbiswas@hotmail.com
}

(Received: 10 April 2021, Accepted: 18 April 2021)

Keywords: Growth, yield, seedling, nitrogen, quinoa

\begin{abstract}
The experiment was conducted at Sher-e-Bangla Agricultural University, Dhaka during Rabi season 2018-19 to find out the influence of planting methods and nitrogen dose on growth and yield of Quinoa-a highly nutritious super food newly introduced in Bangladesh. The experiment was laid out in a Split-plot design with 3 replications. Two planting methods viz., i) seed sowing $\left(\mathrm{M}_{1}\right)$ and ii) seedling planting $\left(\mathrm{M}_{2}\right)$ in the main plot and eight nitrogen doses viz., i) Control $\left(\mathrm{F}_{1}\right)$, ii) $50 \mathrm{~kg} \mathrm{~N} \mathrm{ha}{ }^{-1}$ $\left(\mathrm{F}_{2}\right)$, iii) $100 \mathrm{~kg} \mathrm{~N}^{-1}\left(\mathrm{~F}_{3}\right)$, iv) $150 \mathrm{~kg} \mathrm{~N}^{-1}\left(\mathrm{~F}_{4}\right)$, v) $180 \mathrm{~kg} \mathrm{~N}^{-1}\left(\mathrm{~F}_{5}\right)$, vi) $200 \mathrm{~kg}$ $\mathrm{N} \mathrm{ha}^{-1}\left(\mathrm{~F}_{6}\right)$, vii) $220 \mathrm{~kg} \mathrm{~N}^{-1}\left(\mathrm{~F}_{7}\right)$ and ix) $250 \mathrm{~kg} \mathrm{~N} \mathrm{ha}^{-1}\left(\mathrm{~F}_{8}\right)$ in the sub-plot were assigned. Almost all the studied characters were found statistically significant due to variation in treatments. The higher plant height, leaf number plant $^{-1}$, branch number plant $^{-1}$ and inflorescence height were observed in seedling transplantation than seeds sowing. Increment of nitrogen doses increased the plant height, leaves number plant ${ }^{-1}$, branch number plant ${ }^{-1}$, inflorescence height and SPAD value up to 150-200 kg N ha-1 and then decreased. Higher doses of nitrogenous fertilizer application increased the grain weight. Planting seedling with $150 \mathrm{~kg} \mathrm{~N} \mathrm{ha}^{-1}$ showed the highest seed yield (1227.43 $\left.\mathrm{kg} \mathrm{ha}^{-1}\right)$ which was similar to $180 \mathrm{~kg} \mathrm{~N}$ ha'. Cultivation of quinoa with 25 days old seedlings and $150 \mathrm{~kg} \mathrm{~N} \mathrm{ha}^{-1}$ gave $206.77 \%$ higher yield compared to that of control and it was $64.71 \%$ higher in case of seeds sowing with similar nitrogen dose.
\end{abstract}

\section{Introduction}

Quinoa (Chenopodium quinoa Willd.) has been recognized as a climate resilient crop of great value with most nutritious food crops and the seeds contains high quality protein, which has all the essential amino acids including lysine, methionine and threonine that are scarce in cereals and legumes (Repo-Carrasco et al., 2003). Food and Agriculture Organization (FAO) has identified quinoa as one of the crops that will play an important role in ensuring future food security and designated the year 2013 as the "Year of Quinoa" (Bazile et al., 2015). Worldwide, the demand for quinoa is growing, especially in the health food segment, but current supplies are inadequate. Besides the use for human consumption, quinoa seed has other uses as livestock and poultry feed. The whole plant can be used as green fodder and harvest residues can be fed to the animals. Quinoa seeds are an exceptionally nutritious food source, owing to their high protein content with all essential amino acids, lack of gluten, and high content of several minerals such as $\mathrm{Ca}, \mathrm{Mg}, \mathrm{Fe}$, and it is also rich in vitamins (Bhargara et al., 2006). 
Worldwide quinoa is cultivating using true seeds as planting material, but Ramesh et al. (2019) reported that the crop can also be cultivate using 20 days old seedlings. Hirich (2014) reported that application and suggested the increased seed yield with increasing nitrogen supply. The yield was highest in the $50 \%$ of full irrigation with $240 \mathrm{~kg} \mathrm{~N}$ ha ${ }^{1}$. Another experiment conducted by Shams (2011) with nitrogen fertilization showed that high nitrogen fertilizer dose significantly increased quinoa yield. Alandia et al. (2016) reported that quinoa is a crop which can profit from relatively high levels of $\mathrm{N}$-application under North European conditions.

Agronomy department of Sher-e-Bangla Agricultural University has been working with quinoa and agronomic management package have been identified where November as the optimum sowing time of quinoa in Bangladesh (Biswas and Tanni, 2020). The National Seed Board also registered the crop as 'SAU Quinoa-1' to cultivate in the country. The study was therefore undertaken with planting methods and nitrogen dose to find out the maximum yield potentiality of quinoa.

\section{Materials and Methods}

The experiment was conducted at the Agronomy field of Sher-e-Bangla Agricultural University, Dhaka during the period from November 2018 to April 2019. The farm belongs to the general soil type, Shallow Red Brown Terrace Soils under Tejgaon Series of AEZ-28. The seeds of 'SAU Quinoa-1' was used. The land was finally leveled with leveler to ensure uniform application of water. Urea for nitrogen as per treatment along with TSP and MoP @ $100 \mathrm{~kg}$ P \& $80 \mathrm{~kg} \mathrm{~K} \mathrm{ha}{ }^{-1}$, respectively were used. The whole amount of all fertilizers along with one third of urea was applied as a basal dose and the remaining urea was top dressed in two equal installments at 30 and 45 days after sowing. The seeds were sown on 20 November, 2018 in the main field as well as in surrounding nursery bed from where 25 days old seedlings were uprooted and planted in respective plots maintaining $30 \mathrm{~cm} \times 10 \mathrm{~cm}$ spacing. The experiment was laid out in a Split-plot design with three replications. There were two planting methods viz., i) seed sowing $\left(\mathrm{M}_{1}\right)$ and ii) seedling planting $\left(\mathrm{M}_{2}\right)$ assigned in the main plot and eight nitrogen dose viz., i) control $\left(\mathrm{F}_{1}\right)$, ii) 50 $\mathrm{kg} \mathrm{N}^{-1}\left(\mathrm{~F}_{2}\right)$, iii) $100 \mathrm{~kg} \mathrm{~N}^{-1}\left(\mathrm{~F}_{3}\right)$, iv) $\left.150 \mathrm{~kg} \mathrm{~N}^{-1}\left(\mathrm{~F}_{4}\right), \mathrm{v}\right) 180 \mathrm{~kg} \mathrm{~N}^{-1}\left(\mathrm{~F}_{5}\right)$, vi) $200 \mathrm{~kg} \mathrm{~N}$ ha-1 $\left(\mathrm{F}_{6}\right)$, vii) $220 \mathrm{~kg} \mathrm{~N} \mathrm{ha}^{-1}\left(\mathrm{~F}_{7}\right)$ and ix) $250 \mathrm{~kg} \mathrm{~N}^{-1}\left(\mathrm{~F}_{8}\right)$ in the sub-plot. The gap filling, weeding and other intercultural operations were done as and when necessary. No severe insects and disease infestations were observed during experimentation. The seeds sowing plots were harvested 10 February, 2019 and seedling transplanting on 20 February, 2019. Ten plants per plot was randomly selected for collecting yield contributing and other relevant data like plant height, leaves number plant ${ }^{-1}$, branch number plant ${ }^{-1}$, inflorescence height, SPAD value, 1000grain weight and grain yield. The harvested plants were sundried and threshed from where collected seeds were dried to a constant temperature and weighed. Statistical analyses were done by using the Crop Stat computer package and the mean differences among the treatments were compared by least significant difference test (LSD) at $5 \%$ level of significance following Gomez and Gomez (1984).

\section{Results and Discussion}

\section{Plant height}

\section{Effect of planting method}

Plant height at 21 and 35 days after sowing/planting (DAS/P) and at harvest was significantly differed for planting method (Table 1). The tallest plant at 21 DAP $(12.95 \mathrm{~cm}), 35$ DAP (56.67 
$\mathrm{cm})$ and at harvest $(55.62 \mathrm{~cm})$ was found in seedling planting compared to that of seed sowing. Planting seedling showed 38.80, 12.89 and 6.88\% taller plants at 21, 35 DAS/Planting and at harvest, respectively compared to that of the plants from seed. Biswas and Tanni (2020) was found higher plant height $(62.47 \mathrm{~cm})$ of quinoa from sowing seeds at November 10 .

Table 1. Effect of planting method and nitrogen dose on plant height and leaves number plant ${ }^{-1}$ of quinoa

\begin{tabular}{|c|c|c|c|c|c|}
\hline \multirow[t]{2}{*}{ Treatments } & \multicolumn{2}{|c|}{ Plant height $(\mathrm{cm})$ at } & & \multicolumn{2}{|c|}{ Leaves plant $^{-1}$ (no.) } \\
\hline & $21 \mathrm{DAS} / \mathrm{P}$ & 35 DAS/P & Harvest & $21 \mathrm{DAS} / \mathrm{P}$ & 35 DAS/P \\
\hline \multicolumn{6}{|l|}{ Planting material: } \\
\hline $\mathrm{M}_{1}$ & $9.33 \mathrm{~b}$ & $50.20 \mathrm{~b}$ & 52.04 & $12.03 \mathrm{~b}$ & 71.71 \\
\hline $\mathrm{M}_{2}$ & $12.95 \mathrm{a}$ & $56.67 \mathrm{a}$ & 55.62 & $35.95 \mathrm{a}$ & 68.93 \\
\hline $\operatorname{LSD}_{(0.05)}$ & 1.103 & 4.084 & NS & 4.694 & NS \\
\hline CV $(\%)$ & 8.20 & 4.98 & 8.25 & 15.21 & 30.77 \\
\hline \multicolumn{6}{|l|}{ Nitrogen dose: } \\
\hline $\mathrm{F}_{1}$ & $10.41 \mathrm{bcd}$ & $44.95 \mathrm{c}$ & $47.55 \mathrm{c}$ & $19.17 \mathrm{~b}$ & $61.47 c$ \\
\hline $\mathrm{F}_{2}$ & $10.84 \mathrm{bcd}$ & $50.38 \mathrm{bc}$ & $52.37 \mathrm{abc}$ & $22.50 \mathrm{ab}$ & $73.77 \mathrm{ab}$ \\
\hline $\mathrm{F}_{3}$ & $10.09 \mathrm{~cd}$ & $53.92 \mathrm{ab}$ & $50.88 \mathrm{bc}$ & $24.95 \mathrm{ab}$ & $76.30 \mathrm{ab}$ \\
\hline $\mathrm{F}_{4}$ & $9.83 \mathrm{~d}$ & $54.86 \mathrm{ab}$ & $54.32 \mathrm{ab}$ & $22.73 \mathrm{ab}$ & $77.53 \mathrm{a}$ \\
\hline $\mathrm{F}_{5}$ & $11.71 \mathrm{ab}$ & $57.55 \mathrm{a}$ & $55.86 \mathrm{ab}$ & $27.43 \mathrm{a}$ & $75.43 \mathrm{ab}$ \\
\hline $\mathrm{F}_{6}$ & $11.51 \mathrm{bc}$ & $56.17 \mathrm{a}$ & $56.41 \mathrm{a}$ & $26.68 \mathrm{a}$ & $66.77 \mathrm{abc}$ \\
\hline $\mathrm{F}_{7}$ & $11.64 \mathrm{ab}$ & $55.19 \mathrm{ab}$ & $56.81 \mathrm{a}$ & $24.33 \mathrm{ab}$ & $66.45 \mathrm{abc}$ \\
\hline $\mathrm{F}_{8}^{\prime}$ & $13.07 \mathrm{a}$ & $54.43 \mathrm{ab}$ & $56.45 \mathrm{a}$ & $24.13 \mathrm{ab}$ & $64.85 \mathrm{bc}$ \\
\hline $\operatorname{LSD}_{(0,05)}$ & 1.489 & 5.499 & 5.160 & 6.321 & 11.990 \\
\hline CV $(\%)$ & 11.27 & 8.70 & 8.11 & 22.28 & 14.42 \\
\hline
\end{tabular}

$\mathrm{M}_{1}=$ Sowing seeds, $\mathrm{M}_{2}=$ Planting seedlings, $\mathrm{F}_{1}=0 \mathrm{~kg} \mathrm{~N}^{-1}, \mathrm{~F}_{2}=50 \mathrm{~kg} \mathrm{~N}$ ha ${ }^{-1}, \mathrm{~F}_{3}=100 \mathrm{~kg} \mathrm{~N}^{-1}, \mathrm{~F}_{4}=$ $150 \mathrm{~kg} \mathrm{~N} \mathrm{ha}^{-1}, F_{5}=180 \mathrm{~kg} \mathrm{~N} \mathrm{ha}^{-1}, F_{6}=200 \mathrm{~kg} \mathrm{~N} \mathrm{ha}^{-1}, F_{7}=220 \mathrm{~kg} \mathrm{~N} \mathrm{ha}^{-1}, F_{8}=250 \mathrm{~kg} \mathrm{~N} \mathrm{ha}^{-1}$

\section{Effect of nitrogen dose}

Plant height of quinoa was significantly influenced by nitrogen dose at all studied dates. At 21 DAS/P, the highest plant height $(13.07 \mathrm{~cm})$ was recorded in $\mathrm{F}_{8}\left(250 \mathrm{~kg} \mathrm{~N}^{-1}\right)$ that similar to $\mathrm{F}_{7}$ and $\mathrm{F}_{5}$ whereas the lowest plant height $(9.83 \mathrm{~cm})$ by $F_{4}$ that similar to $F_{3}, F_{2}$ and $F_{1}$ (Table 1). Almost similar trend was also observed at 35 DAS/P but at harvest, application of 150 to $250 \mathrm{~kg} \mathrm{~N} \mathrm{ha}{ }^{-1}$ resulted similar and significantly higher plant height and no nitrogen application treatment gave the shortest plant height $(47.55 \mathrm{~cm})$. Geren $(2015)$ also reported that the plant height of quinoa increased noticeably by increasing nitrogen fertilizer rate up to $175 \mathrm{~kg}$ $\mathrm{N}$ ha ${ }^{-1}$. Fawy et al. (2017) reported 33\% higher plant height of quinoa by $240 \mathrm{~kg} \mathrm{~N}$ ha-1 whereas Weisany et al. (2013) also reported 33\% higher plant height of quinoa by soil application of nitrogen than control.

\section{Interaction effect of planting method and nitrogen dose}

The interaction effect of planting method and nitrogen dose showed significant variations of plant height. The tallest plant at $21 \mathrm{DAS} / \mathrm{P}$ was given by $\mathrm{M}_{2} \mathrm{~F}_{8}(16.30 \mathrm{~cm})$ that similar to $\mathrm{M}_{2} \mathrm{~F}_{7}$ $(15.30 \mathrm{~cm})$ and the shortest plant $(8.08 \mathrm{~cm})$ found in $\mathrm{M}_{1} \mathrm{~F}_{7}$ that similar to all nitrogen levels under seed sowing. At $35 \mathrm{DAS} / \mathrm{P}$, the tallest plant $(61.37 \mathrm{~cm})$ was resulted in $\mathrm{M}_{2} \mathrm{~F}_{3}$ that similar to all nitrogen doses of seedling planting except no nitrogen application and the shortest plant $\left(43.30 \mathrm{~cm}\right.$ ) observed in $\mathrm{M}_{1} \mathrm{~F}_{1}$ which was at par with $\mathrm{M}_{1} \mathrm{~F}_{2}, \mathrm{M}_{1} \mathrm{~F}_{4}, \mathrm{M}_{1} \mathrm{~F}_{4}$ and $\mathrm{M}_{2} \mathrm{~F}_{1}$ combinations (Table 2). At harvest, the tallest plant $(60.53 \mathrm{~cm})$ was found in $\mathrm{M}_{1} \mathrm{~F}_{5}$ and the shortest plant $(43.11 \mathrm{~cm})$ at $\mathrm{M}_{1} \mathrm{~F}_{1}$. 


\section{Number of leaves plant ${ }^{-1}$}

\section{Effect of planting method}

The maximum number of leaves plant ${ }^{-1}(35.95)$ at 21 DAP was recorded in seedling planting as compared to that of sowing seeds (12.03) but at 35 DAS, the scenario was reverse where maximum leaves plant (71.71) was given by the plants of seeds though no significant variation observed between them (Table 1). Sadia (2018) also reported 29.19 leaves plant ${ }^{-1}$ of quinoa using seeds as planting material.

\section{Effect of nitrogen dose}

At $21 \mathrm{DAS} / \mathrm{P}$, the maximum number of leaves plant ${ }^{-1}$ (27.43) was observed in $\mathrm{F}_{5}$ that similar to $\mathrm{F}_{6}$ whereas the lowest number of leaves plant ${ }^{-1}$ in control plants (Table 1). Similar trend was also shown in 35 DAS/P. Application of $120 \mathrm{~kg} \mathrm{~N}^{-1}$ gave 33.80 leaves plant ${ }^{-1}$ of quinoa as reported by Sadia (2018).

\section{Interaction of planting method and nitrogen dose}

The number of leaves plant ${ }^{-1}$ was significantly influenced by the interaction of planting method and nitrogen dose and the highest number of leaves plant ${ }^{-1}$ at 21 DAS/P was observed in $\mathrm{M}_{2} \mathrm{~F}_{5}$ (41.80) that similar to $\mathrm{M}_{2} \mathrm{~F}_{6}$ (41.03). No variation was recorded among the interactions of $\mathrm{M}_{1}$ irrespective of all nitrogen doses (Table 1 ) that exhibited the lower number of leaves plant ${ }^{-1}$. The scenario was different at 35 DAS/P where $\mathrm{M}_{1} \mathrm{~F}_{5}$ resulted the highest number of leaves plant ${ }^{-1}$ and the lowest in $\mathrm{M}_{2} \mathrm{~F}_{1}$ interaction (59.13).

Table 2. Effect of planting method and nitrogen dose on plant height and number of leaves plant $^{-1}$ of quinoa

\begin{tabular}{cccccc}
\hline \multirow{2}{*}{ Treatments } & \multicolumn{3}{c}{ Plant height (cm) at } & \multicolumn{2}{c}{ Leaves plant $^{-1}$ (no.) at } \\
\cline { 2 - 6 } & 21 DAS/P & 35 DAS/P & Harvest & 21 DAS/P & 35 DAS/P \\
\hline $\mathrm{M}_{1} \mathrm{~F}_{1}$ & $9.49 \mathrm{c}-\mathrm{f}$ & $43.30 \mathrm{f}$ & $43.11 \mathrm{f}$ & $13.20 \mathrm{~d}$ & $63.80 \mathrm{bcd}$ \\
$\mathrm{M}_{1} \mathrm{~F}_{2}$ & $10.41 \mathrm{cde}$ & $45.27 \mathrm{ef}$ & $48.07 \mathrm{def}$ & $12.93 \mathrm{~d}$ & $68.07 \mathrm{a}-\mathrm{d}$ \\
$\mathrm{M}_{1} \mathrm{~F}_{3}$ & $9.04 \mathrm{def}$ & $46.47 \mathrm{def}$ & $45.67 \mathrm{ef}$ & $11.67 \mathrm{~d}$ & $69.33 \mathrm{a}-\mathrm{d}$ \\
$\mathrm{M}_{1} \mathrm{~F}_{4}$ & $8.95 \mathrm{ef}$ & $51.00 \mathrm{c}-\mathrm{f}$ & $54.30 \mathrm{a}-\mathrm{d}$ & $10.67 \mathrm{~d}$ & $77.00 \mathrm{abc}$ \\
$\mathrm{M}_{1} \mathrm{~F}_{5}$ & $9.81 \mathrm{c}-\mathrm{f}$ & $57.40 \mathrm{abc}$ & $60.53 \mathrm{a}$ & $13.07 \mathrm{~d}$ & $84.67 \mathrm{a}$ \\
$\mathrm{M}_{1} \mathrm{~F}_{6}$ & $8.99 \mathrm{ef}$ & $53.20 \mathrm{bcd}$ & $54.79 \mathrm{a}-\mathrm{d}$ & $12.33 \mathrm{~d}$ & $68.27 \mathrm{a}-\mathrm{d}$ \\
$\mathrm{M}_{1} \mathrm{~F}_{7}$ & $8.08 \mathrm{f}$ & $52.27 \mathrm{~b}-\mathrm{e}$ & $55.93 \mathrm{abc}$ & $10.80 \mathrm{~d}$ & $74.33 \mathrm{a}-\mathrm{d}$ \\
$\mathrm{M}_{1} \mathrm{~F}_{8}$ & $9.85 \mathrm{c}-\mathrm{f}$ & $52.67 \mathrm{~b}-\mathrm{e}$ & $53.90 \mathrm{a}-\mathrm{d}$ & $11.60 \mathrm{~d}$ & $68.20 \mathrm{a}-\mathrm{d}$ \\
$\mathrm{M}_{2} \mathrm{~F}_{1}$ & $11.33 \mathrm{c}$ & $46.60 \mathrm{def}$ & $51.99 \mathrm{~b}-\mathrm{e}$ & $25.13 \mathrm{c}$ & $59.13 \mathrm{~d}$ \\
$\mathrm{M}_{2} \mathrm{~F}_{2}$ & $11.27 \mathrm{c}$ & $55.49 \mathrm{abc}$ & $56.67 \mathrm{abc}$ & $32.07 \mathrm{bc}$ & $79.47 \mathrm{ab}$ \\
$\mathrm{M}_{2} \mathrm{~F}_{3}$ & $11.13 \mathrm{~cd}$ & $61.37 \mathrm{a}$ & $56.09 \mathrm{abc}$ & $38.23 \mathrm{ab}$ & $83.27 \mathrm{a}$ \\
$\mathrm{M}_{2} \mathrm{~F}_{4}$ & $10.70 \mathrm{cde}$ & $58.72 \mathrm{abc}$ & $54.33 \mathrm{a}-\mathrm{d}$ & $34.80 \mathrm{ab}$ & $78.07 \mathrm{abc}$ \\
$\mathrm{M}_{2} \mathrm{~F}_{5}$ & $13.60 \mathrm{~b}$ & $57.70 \mathrm{abc}$ & $51.19 \mathrm{cde}$ & $41.80 \mathrm{a}$ & $66.20 \mathrm{bcd}$ \\
$\mathrm{M}_{2} \mathrm{~F}_{6}$ & $14.03 \mathrm{~b}$ & $59.13 \mathrm{ab}$ & $58.03 \mathrm{abc}$ & $41.03 \mathrm{a}$ & $65.27 \mathrm{bcd}$ \\
$\mathrm{M}_{2} \mathrm{~F}_{7}$ & $15.20 \mathrm{ab}$ & $58.11 \mathrm{abc}$ & $57.68 \mathrm{abc}$ & $37.87 \mathrm{ab}$ & $58.57 \mathrm{~d}$ \\
$\mathrm{M}_{2} \mathrm{~F}_{8}$ & $16.30 \mathrm{a}$ & $56.20 \mathrm{abc}$ & $59.00 \mathrm{ab}$ & $36.67 \mathrm{ab}$ & $61.50 \mathrm{~cd}$ \\
\hline $\mathrm{LSD}_{(0.05)}$ & 2.09 & 7.78 & 7.30 & 8.94 & 16.96 \\
$\mathrm{CV}_{(\%)}$ & 11.27 & 8.70 & 8.11 & 22.28 & 14.42 \\
\hline
\end{tabular}

$\mathrm{M}_{1}=$ Sowing seeds, $\mathrm{M}_{2}=$ Planting seedlings, $\mathrm{F}_{1}=0 \mathrm{~kg} \mathrm{~N} \mathrm{ha}{ }^{-1}, \mathrm{~F}_{2}=50 \mathrm{~kg} \mathrm{~N}^{-1}, \mathrm{~F}_{3}=100 \mathrm{~kg} \mathrm{~N}^{-1}, \mathrm{~F}_{4}=$ $150 \mathrm{~kg} \mathrm{~N} h a^{-1}, F_{5}=180 \mathrm{~kg} \mathrm{~N} \mathrm{ha}^{-1}, F_{6}=200 \mathrm{~kg} \mathrm{~N} \mathrm{ha}^{-1}, F_{7}=220 \mathrm{~kg} \mathrm{~N} \mathrm{ha}^{-1}, F_{8}=250 \mathrm{~kg} \mathrm{~N} \mathrm{ha}^{-1}$ 


\section{Number of branches plant ${ }^{-1}$}

\section{Effect of planting method}

The higher number of branches plant ${ }^{-1}$ at harvest was recorded from the plants of seedling (19.87) compared to that of seeds (10.89) which was $82.46 \%$ higher (Table 3). Sadia (2018) reported 17.67 branches plant $^{-1}$ of quinoa from seeds as planting method.

\section{Effect of nitrogen dose}

Application of various levels of nitrogen resulted significant variations on branch number plant ${ }^{-1}$ of quinoa and the $100 \mathrm{~kg} \mathrm{~N}^{-1}$ gave highest number of branches plant ${ }^{-1}$ (17.07) that similar to all other doses except control, 220 and $250 \mathrm{~kg} \mathrm{~N}^{-1}$ (Table 3). The lowest number of branches plant $^{-1}$ (11.53) was found in $250 \mathrm{~kg} \mathrm{~N}$ ha-1. Application of $120 \mathrm{~kg} \mathrm{~N}^{-1} \mathrm{ka}^{-1}$ resulted 20.00 branches plant ${ }^{-1}$ of quinoa as reported by Sadia (2018).

Table 3. Effect of planting method and nitrogen dose on yield and other crop characters of quinoa

\begin{tabular}{|c|c|c|c|c|c|}
\hline Treatments & $\begin{array}{c}\text { Branches plant } \\
1 \text { (no.) }\end{array}$ & $\begin{array}{c}\text { Inflorescence } \\
\text { length }(\mathrm{cm})\end{array}$ & $\begin{array}{l}\text { SPAD } \\
\text { value }\end{array}$ & $\begin{array}{l}\text { 1000-seed } \\
\text { weight }(\mathrm{g})\end{array}$ & $\begin{array}{l}\text { Seed yield } \\
\left(\mathrm{kg} \mathrm{ha}^{-1}\right)\end{array}$ \\
\hline \multicolumn{6}{|l|}{ Planting material: } \\
\hline & $10.89 \mathrm{~b}$ & $23.69 \mathrm{~b}$ & 55.53 & 2.94 & 945.46 \\
\hline $\begin{array}{l}M_{1} \\
M_{2}\end{array}$ & $19.87 \mathrm{a}$ & $41.28 \mathrm{a}$ & 55.66 & 2.97 & 934.15 \\
\hline $\operatorname{LSD}_{(0.05)}$ & 1.67 & 3.62 & NS & NS & NS \\
\hline CV $(\%)$ & 11.18 & 5.01 & 6.06 & 3.20 & 7.68 \\
\hline \multicolumn{6}{|l|}{ Nitrogen dose: } \\
\hline $\mathrm{F}_{1}$ & $15.07 \mathrm{bc}$ & $26.53 c$ & $38.13 \mathrm{~d}$ & $2.67 \mathrm{~d}$ & $538.19 \mathrm{f}$ \\
\hline $\mathrm{F}_{2}$ & $16.60 \mathrm{ab}$ & $29.95 \mathrm{bc}$ & $46.02 \mathrm{c}$ & $2.75 \mathrm{c}$ & $756.71 e$ \\
\hline $\mathrm{F}_{3}$ & $17.07 \mathrm{a}$ & $33.20 \mathrm{ab}$ & $55.77 \mathrm{~b}$ & $2.87 \mathrm{~b}$ & $993.22 \mathrm{~cd}$ \\
\hline $\mathrm{F}_{4}$ & $16.77 \mathrm{ab}$ & $36.02 \mathrm{a}$ & $59.34 \mathrm{ab}$ & $3.06 \mathrm{a}$ & $1170.64 \mathrm{a}$ \\
\hline $\mathrm{F}_{5}$ & $16.40 \mathrm{ab}$ & $33.53 \mathrm{ab}$ & $57.75 \mathrm{~b}$ & $3.06 \mathrm{a}$ & $1097.77 \mathrm{ab}$ \\
\hline $\mathrm{F}_{6}$ & $15.63 \mathrm{abc}$ & $35.98 \mathrm{a}$ & $64.61 \mathrm{a}$ & $3.09 \mathrm{a}$ & $1033.37 \mathrm{bc}$ \\
\hline $\mathrm{F}_{7}$ & $13.97 \mathrm{c}$ & $32.92 \mathrm{ab}$ & $61.85 \mathrm{ab}$ & $3.08 \mathrm{a}$ & $1003.73 \mathrm{~cd}$ \\
\hline $\mathrm{F}_{8}$ & $11.53 \mathrm{~d}$ & $31.77 \mathrm{ab}$ & $61.32 \mathrm{ab}$ & $3.10 \mathrm{a}$ & $924.80 \mathrm{~d}$ \\
\hline $\mathrm{LSD}_{(0.05)}$ & 1.83 & 4.87 & 6.20 & 0.06 & 87.24 \\
\hline CV $(\%)$ & 10.08 & 12.67 & 9.44 & 1.80 & 7.85 \\
\hline
\end{tabular}

$\mathrm{M}_{1}=$ Sowing seeds, $\mathrm{M}_{2}=$ Planting seedlings, $\mathrm{F}_{1}=0 \mathrm{~kg} \mathrm{~N}$ ha ${ }^{-1}, \mathrm{~F}_{2}=50 \mathrm{~kg} \mathrm{~N}$ ha ${ }^{-1}, \mathrm{~F}_{3}=100 \mathrm{~kg} \mathrm{~N} \mathrm{ha}^{-1}, \mathrm{~F}_{4}=$ $150 \mathrm{~kg} \mathrm{~N} \mathrm{ha}^{-1}, \mathrm{~F}_{5}=180 \mathrm{~kg} \mathrm{~N}^{-1}, \mathrm{~F}_{6}=200 \mathrm{~kg} \mathrm{~N} \mathrm{ha}^{-1}, \mathrm{~F}_{7}=220 \mathrm{~kg} \mathrm{~N}^{-1}, \mathrm{~F}_{8}=250 \mathrm{~kg} \mathrm{~N} \mathrm{ha}^{-1}$

\section{Interaction of planting method and nitrogen dose}

Interaction of planting method and nitrogen dose showed significant variations for branches number plant ${ }^{-1}$ where $\mathrm{M}_{2} \mathrm{~F}_{3}$ gave significantly the higher number of branches plant ${ }^{-1}$ (23.13) that similar to $\mathrm{M}_{2} \mathrm{~F}_{4}$ (22.80) and $\mathrm{M}_{2} \mathrm{~F}_{2}$ (22.67) but the lowest number of branches plant ${ }^{-1}$ in $\mathrm{M}_{1} \mathrm{~F}_{1}$ (9.80) that similar to all other nitrogen doses of seeds sowing method except $\mathrm{M}_{1} \mathrm{~F}_{5}$ (Table 4). Biswas and Tanni (2020) reported 25.20 branches plant $^{-1}$ of quinoa from November-10 sowing of seeds with $180 \mathrm{~kg} \mathrm{~N} \mathrm{ha}^{-1}$.

\section{Inflorescence length at harvest}

\section{Effect of planting method}

The higher length of inflorescence was recorded in seedling planting $(41.28 \mathrm{~cm})$ compared to that of seeds sowing $(23.69 \mathrm{~cm})$ which was $74.25 \%$ higher than seed sowing method (Table 3 ). 
Similar inflorescence length $(22.01 \mathrm{~cm})$ of quinoa using seeds as planting material was also reported by Biswas and Tanni (2020). Ramesh et al. (2019) also reported similar inflorescence length $(19.00-23.50 \mathrm{~cm})$ of quinoa in India.

\section{Effect of nitrogen dose}

Application of various levels of nitrogen fertilizer resulted significant variations on inflorescence length of quinoa and the $200 \mathrm{~kg} \mathrm{~N}^{-1}$ gave maximum length $(36.02 \mathrm{~cm})$ that similar to all other doses except control and $50 \mathrm{~kg} \mathrm{~N}^{-1}$ (Table 3). The lowest inflorescence length $(26.53 \mathrm{~cm})$ was found in control plots. Application of $120 \mathrm{~kg} \mathrm{~N}^{-1}$ resulted $18.56 \mathrm{~cm}$ length of inflorescence as reported by Sadia (2018).

\section{Interaction of planting method and nitrogen dose}

Interaction of planting material and nitrogen dose showed significant variations for inflorescence length where $\mathrm{M}_{2} \mathrm{~F}_{3}$ gave maximum length $(45.13 \mathrm{~cm})$ that similar to almost all other treatments of seedling planting except $\mathrm{M}_{2} \mathrm{~F}_{2}$ and $\mathrm{M}_{2} \mathrm{~F}_{1}$ and all treatments of seeds sowing. The lowest inflorescence length $(17.50 \mathrm{~cm})$ was observed in $\mathrm{M}_{1} \mathrm{~F}_{1}$ that similar to $\mathrm{M}_{1} \mathrm{~F}_{2}, \mathrm{M}_{1} \mathrm{~F}_{3}, \mathrm{M}_{1} \mathrm{~F}_{7}$ and $\mathrm{M}_{1} \mathrm{~F}_{8}$ interactions (Table 4). Similar inflorescence length $(21.10-31.70 \mathrm{~cm})$ was also reported by Rao and Shahid (2012).

Table 4. Interaction effect of planting method and nitrogen dose on yield and other crop characters of quinoa

\begin{tabular}{cccccc}
\hline $\begin{array}{c}\text { Treatment } \\
\text { combinations }\end{array}$ & $\begin{array}{c}\text { Branches } \\
\text { plant }^{-1} \text { (no.) }\end{array}$ & $\begin{array}{c}\text { Inflorescence } \\
\text { height }(\mathbf{c m})\end{array}$ & $\begin{array}{c}\text { SPAD } \\
\text { value }\end{array}$ & $\begin{array}{c}\text { 1000-seed } \\
\text { weight (g) }\end{array}$ & $\begin{array}{c}\text { Seed yield } \\
\text { (kg ha } \mathbf{~} \text { ) }^{\text {(ng }}\end{array}$ \\
\hline $\mathrm{M}_{1} \mathrm{~F}_{1}$ & $9.80 \mathrm{e}$ & $17.50 \mathrm{~h}$ & $29.41 \mathrm{~h}$ & $2.62 \mathrm{~d}$ & $676.24 \mathrm{~g}$ \\
$\mathrm{M}_{1} \mathrm{~F}_{2}$ & $10.53 \mathrm{de}$ & $21.10 \mathrm{gh}$ & $40.79 \mathrm{~g}$ & $2.72 \mathrm{c}$ & $841.53 \mathrm{f}$ \\
$\mathrm{M}_{1} \mathrm{~F}_{3}$ & $11.00 \mathrm{de}$ & $21.27 \mathrm{fgh}$ & $58.53 \mathrm{a}-\mathrm{e}$ & $2.88 \mathrm{~b}$ & $939.12 \mathrm{def}$ \\
$\mathrm{M}_{1} \mathrm{~F}_{4}$ & $10.73 \mathrm{de}$ & $28.13 \mathrm{ef}$ & $64.34 \mathrm{ab}$ & $3.06 \mathrm{a}$ & $1113.85 \mathrm{abc}$ \\
$\mathrm{M}_{1} \mathrm{~F}_{5}$ & $12.40 \mathrm{de}$ & $28.97 \mathrm{de}$ & $59.36 \mathrm{a}-\mathrm{e}$ & $3.08 \mathrm{a}$ & $1060.90 \mathrm{bcd}$ \\
$\mathrm{M}_{1} \mathrm{~F}_{6}$ & $11.00 \mathrm{de}$ & $27.63 \mathrm{efg}$ & $66.37 \mathrm{a}$ & $3.06 \mathrm{a}$ & $1030.32 \mathrm{bcd}$ \\
$\mathrm{M}_{1} \mathrm{~F}_{7}$ & $11.07 \mathrm{de}$ & $23.83 \mathrm{e}-\mathrm{h}$ & $63.47 \mathrm{ab}$ & $3.05 \mathrm{a}$ & $1013.79 \mathrm{bcd}$ \\
$\mathrm{M}_{1} \mathrm{~F}_{8}$ & $10.60 \mathrm{de}$ & $21.10 \mathrm{gh}$ & $61.99 \mathrm{abc}$ & $3.09 \mathrm{a}$ & $887.90 \mathrm{ef}$ \\
$\mathrm{M}_{2} \mathrm{~F}_{1}$ & $20.33 \mathrm{~b}$ & $35.57 \mathrm{~cd}$ & $46.84 \mathrm{f}$ & $2.71 \mathrm{c}$ & $400.13 \mathrm{~h}$ \\
$\mathrm{M}_{2} \mathrm{~F}_{2}$ & $22.67 \mathrm{ab}$ & $38.80 \mathrm{abc}$ & $51.24 \mathrm{ef}$ & $2.77 \mathrm{c}$ & $671.88 \mathrm{~g}$ \\
$\mathrm{M}_{2} \mathrm{~F}_{3}$ & $23.13 \mathrm{a}$ & $45.13 \mathrm{a}$ & $53.00 \mathrm{def}$ & $2.87 \mathrm{~b}$ & $1047.31 \mathrm{bcd}$ \\
$\mathrm{M}_{2} \mathrm{~F}_{4}$ & $22.80 \mathrm{ab}$ & $43.90 \mathrm{ab}$ & $54.35 \mathrm{c}-\mathrm{f}$ & $3.06 \mathrm{a}$ & $1227.43 \mathrm{a}$ \\
$\mathrm{M}_{2} \mathrm{~F}_{5}$ & $20.40 \mathrm{~b}$ & $38.10 \mathrm{bc}$ & $56.14 \mathrm{~b}-\mathrm{e}$ & $3.03 \mathrm{a}$ & $1134.65 \mathrm{ab}$ \\
$\mathrm{M}_{2} \mathrm{~F}_{6}$ & $20.27 \mathrm{~b}$ & $44.33 \mathrm{ab}$ & $62.85 \mathrm{abc}$ & $3.11 \mathrm{a}$ & $1036.42 \mathrm{bcd}$ \\
$\mathrm{M}_{2} \mathrm{~F}_{7}$ & $16.87 \mathrm{c}$ & $42.00 \mathrm{abc}$ & $60.23 \mathrm{a}-\mathrm{d}$ & $3.12 \mathrm{a}$ & $993.66 \mathrm{cde}$ \\
$\mathrm{M}_{2} \mathrm{~F}_{8}$ & $12.47 \mathrm{~d}$ & $42.43 \mathrm{abc}$ & $60.65 \mathrm{a}-\mathrm{d}$ & $3.12 \mathrm{a}$ & $961.70 \mathrm{def}$ \\
\hline $\mathrm{LSD}_{(0.05)}$ & 2.59 & 6.87 & 8.77 & 0.09 & 123.37 \\
$\mathrm{CV}(\%)$ & 10.08 & 12.67 & 9.44 & 1.80 & 7.85 \\
\hline
\end{tabular}

$M_{1}=$ Sowing seeds, $M_{2}=$ Planting seedlings, $F_{1}=0 \mathrm{~kg} \mathrm{~N} \mathrm{ha}^{-1}, F_{2}=50 \mathrm{~kg} \mathrm{~N}^{-1}, F_{3}=100 \mathrm{~kg} \mathrm{~N} \mathrm{ha}^{-1}, F_{4}=$ $150 \mathrm{~kg} \mathrm{~N} \mathrm{ha}^{-1}, F_{5}=180 \mathrm{~kg} \mathrm{~N} \mathrm{ha}^{-1}, F_{6}=200 \mathrm{~kg} \mathrm{~N} \mathrm{ha}^{-1}, F_{7}=220 \mathrm{~kg} \mathrm{~N} \mathrm{ha}^{-1}, F_{8}=250 \mathrm{~kg} \mathrm{~N} \mathrm{ha}^{-1}$

\section{SPAD value}

\section{Effect of planting method}

There was no significant variation observed between the two planting methods for SPAD value though the numerically higher value (55.66) was found in seedling planting compared to that of seed sowing (55.53) (Table 3). 


\section{Effect of nitrogen dose}

Various levels of nitrogen resulted significant variations on SPAD value of quinoa and the maximum value (64.61) was observed in $200 \mathrm{~kg} \mathrm{~N}^{-1}$ that similar to $\mathrm{F}_{7}(61.85), \mathrm{F}_{8}(61.32)$ and $\mathrm{F}_{4}$ (59.34) (Table 3). The lowest SPAD value $(38.13 \mathrm{~cm})$ was found in control plants.

\section{Interaction of planting method and nitrogen dose}

Interaction of planting method and nitrogen dose showed significant variations for SPAD value where $\mathrm{M}_{1} \mathrm{~F}_{6}$ gave significantly the maximum value (66.37) that similar to all other nitrogen doses of seed sowing except $\mathrm{M}_{1} \mathrm{~F}_{1}$ and $\mathrm{M}_{1} \mathrm{~F}_{2}$ as well as $\mathrm{M}_{2} \mathrm{~F}_{6}, \mathrm{M}_{2} \mathrm{~F}_{7}$ and $\mathrm{M}_{2} \mathrm{~F}_{8}$. The lowest SPAD value (29.41) was observed in $\mathrm{M}_{1} \mathrm{~F}_{1}$ (Table 4).

\section{Weight of 1000 seeds}

\section{Effect of planting method}

The 1000-seed weight was not significantly varied for the two planting methods where seedlings planting gave numerically higher 1000 -seed weight $(2.97 \mathrm{~g})$ compared to that of seeds sowing $(2.94 \mathrm{~g})$ (Table 3). Biswas and Tanni (2020) reported that the 1000-seed weight of quinoa varied significantly with sowing dates that ranges from 1.17-2.58 g for March to November sowing with seed sowing method.

\section{Effect of nitrogen dose}

Application of various doses of nitrogen fertilizer resulted significant variations on 1000-seed weight and the maximum weight $(3.10 \mathrm{~g})$ was observed in $\mathrm{F}_{8}\left(250 \mathrm{~kg} \mathrm{~N} \mathrm{~N}^{-1}\right)$ that similar to $\mathrm{F}_{6}$ $(3.09 \mathrm{~g}), \mathrm{F}_{7}(3.08 \mathrm{~g}), \mathrm{F}_{5}(3.06 \mathrm{~g})$ and $\mathrm{F}_{4}(3.06 \mathrm{~g})$ (Table 3). The lowest 1000 -seed weight $(2.67$ g) was found in control treatment that showed $13.87 \%$ lower weight than $F_{8}$ treatment. Similar higher 1000-seed weight $(3.06 \mathrm{~g})$ of quinoa was also reported by application of $187.50 \mathrm{~kg}$ $\mathrm{N}^{-1}$ (Kansomjet et al., 2017) but dissimilar opinion was also given by Basra et al. (2014) who stated that 1000-grain weight of quinoa not affected by nitrogen fertilization from 0 to $120 \mathrm{~kg} \mathrm{~N}$ $\mathrm{ha}^{-1}$.

\section{Interaction of planting method and nitrogen dose}

Interaction of planting method and nitrogen dose showed significant variations for 1000 -seed weight where $\mathrm{M}_{2} \mathrm{~F}_{8}$ and $\mathrm{M}_{2} \mathrm{~F}_{7}$ gave significantly the highest identical 1000-seed weight (3.12 g) that similar to $\mathrm{F}_{6}, \mathrm{~F}_{5}$ and $\mathrm{F}_{4}$ irrespective of their planting material (Table 4). Sowing seeds with $120 \mathrm{~kg} \mathrm{~N} \mathrm{ha}{ }^{-1}$ resulted similar $(2.84 \mathrm{~g}) 1000$-seed weight of quinoa as reported by Sadia 92018).

\section{Seed yield}

\section{Effect of planting method}

There was no significant variation of seed yield observed between the two planting methods. The numerically higher seed yield $\left(945.46 \mathrm{~kg} \mathrm{ha}^{-1}\right)$ was observed in seed sowing compared to that of seedling transplanting $\left(934.15 \mathrm{~kg} \mathrm{ha}^{-1}\right)$ (Table 3). Similar seed yield of quinoa (1.16 $\left.\mathrm{t} \mathrm{ha} \mathrm{h}^{-1}\right)$ was also reported by Biswas and Tanni (2020).

\section{Effect of nitrogen dose}

Application of various doses of nitrogen fertilizer resulted significant variations on seed yield of quinoa and the highest yield (1170.64 $\left.\mathrm{kg} \mathrm{ha}^{-1}\right)$ observed in $\mathrm{F}_{4}\left(150 \mathrm{~kg} \mathrm{~N}^{-1}\right)$ that similar $(1097.77$ $\left.\mathrm{kg} \mathrm{ha}^{-1}\right)$ to $\mathrm{F}_{5}\left(180 \mathrm{~kg} \mathrm{~N}^{-1}\right)$ and followed by $\mathrm{F}_{6}\left(1033.37 \mathrm{~kg} \mathrm{ha}^{-1}\right)$ (Table 3$)$. The lowest seed yield 
(538.19 $\mathrm{kg} \mathrm{ha}^{-1}$ ) was found in control treatment. Application of $150 \mathrm{~kg} \mathrm{~N}^{-1}\left(\mathrm{~F}_{4}\right)$ showed $117.51 \%$ higher yield than control (no nitrogenous fertilizer application). Kansomjet et al. (2017) was found higher seed yield $\left(2641.70 \mathrm{~kg} \mathrm{ha}^{-1}\right)$ of quinoa by application of $93.75 \mathrm{~kg} \mathrm{~N} \mathrm{ha}-1$ and its increment reduced seed yield (Lavini et al., 2014). Jacobsen and Christiansen (2016) reported that quinoa yield increased significantly with an application up to $180 \mathrm{~kg} \mathrm{~N} \mathrm{ha}^{-1}$. In another study Jacobsen et al. (1994) reported that seed yield in quinoa increased with increasing $\mathrm{N}$ application, however, on the other hand only small yield decreases were seen when decreasing $\mathrm{N}$-level from highest $\mathrm{N}$ application of $160 \mathrm{~kg} \mathrm{ha}^{-1}$.

\section{Interaction of planting method and nitrogen dose}

Interaction of planting method and nitrogen dose showed significant variations for seed yield of quinoa where $\mathrm{M}_{2} \mathrm{~F}_{4}$ gave significantly the maximum seed yield (1227.43 $\left.\mathrm{kg} \mathrm{ha}^{-1}\right)$ that similar to $\mathrm{M}_{2} \mathrm{~F}_{5}\left(1134.65 \mathrm{~kg} \mathrm{ha}^{-1}\right)$ and $\mathrm{M}_{1} \mathrm{~F}_{4}\left(1113.85 \mathrm{~kg} \mathrm{ha}^{-1}\right)$. The lowest seed yield $\left(400.13 \mathrm{~kg} \mathrm{ha}^{-1}\right)$ was observed in $\mathrm{M}_{2} \mathrm{~F}_{1}$ that followed by $\mathrm{M}_{1} \mathrm{~F}_{1}\left(676.24 \mathrm{~kg} \mathrm{ha}^{-1}\right)$ (Table 4). The values obtained correspond to those reported by Erley et al. (2005) that nitrogen fertilizer rates at 80 and $120 \mathrm{~kg}$ $\mathrm{N}$ ha ${ }^{-1}$ had the highest of quinoa grain yield at 3,083 and $3,495 \mathrm{~kg} \mathrm{ha}{ }^{-1}$, respectively. Kaveeta et al. (2009), Oelke et al. (1992), Basra et al. (2014), Carlsson et al. (1984), Thanapornpoonpong (2004), Shams (2012), Gomaa (2013) and Geren (2015) also reported that nitrogen fertilizer rates affected grain yield of quinoa due to promoting vegetative growth behaviour of nitrogen fertilizer. Nitrogen had increased ability for photosynthesis and photosynthate translocation to promote grain and these results agreed with Thanapornpoonpong (2004) who noticed that seed yield plant ${ }^{-1}$ increased with increasing nitrogen fertilizer rates. Kansomjet et al. (2017) reported that nitrogen fertilizer rate of 93.75, 187.50 and $312.50 \mathrm{~kg} \mathrm{~N}$ ha ${ }^{-1}$ results on higher seed yield of quinoa than those of control. In Denmark, it is recommended to apply $80-120 \mathrm{~kg}$ of $\mathrm{N} \mathrm{ha}^{-1}$ at crop establishment in the spring to obtain a yield of about $2 \mathrm{t} \mathrm{ha}^{-1}$ of seed. In Germany quinoa responded strongly to $\mathrm{N}$ fertilization to $120 \mathrm{~kg} \mathrm{~N}$ ha $^{-1}$, with a $94 \%$ yield increase compared to $0 \mathrm{~N}$ (Schulte auf'm Erley et al., 2005). Estimated yield potential may exceed the observed yields, indicating that even higher rates of nitrogen application may increase yield (Hirich et al., 2013).

\section{Conclusion}

The planting method had significant effect on plant height at earlier stages, branches number plant $^{-1}$ and inflorescence height where seedling planting method showed superior performance but the other studied parameters resulted non-significant variations. The nitrogen dose significantly influenced all the studied parameters where no nitrogen (control) as well as higher nitrogen dose negatively influenced on yield and other characters. Higher yield (1170.64 kg ha-1) was obtained in $\mathrm{F}_{4}\left(150 \mathrm{~kg} \mathrm{~N}^{-1}\right)$ that similar $\left(1097.77 \mathrm{~kg} \mathrm{ha}^{-1}\right)$ to $\mathrm{F}_{5}\left(180 \mathrm{~kg} \mathrm{~N}^{-1}\right)$. The highest grain yield (1227.43 kg ha-1) was observed in $\mathrm{M}_{2} \mathrm{~F}_{4}$ that similar to $\mathrm{M}_{2} \mathrm{~F}_{5}\left(1134.65 \mathrm{~kg} \mathrm{ha}^{-1}\right)$ and $\mathrm{M}_{1} \mathrm{~F}_{4}$ (1113.85 kg ha-1) and the lowest grain yield was observed in $\mathrm{M}_{2} \mathrm{~F}_{1}\left(400.13 \mathrm{~kg} \mathrm{ha}{ }^{-1}\right)$. Based on the results of the study, it may be concluded that Quinoa can also be grown in Bangladesh by 25 days old seedling with 150 to $180 \mathrm{~kg} \mathrm{~N}^{-1}$. However, to reach a specific conclusion and recommendation more experiments are suggested with different levels of other fertilizers and in different Agro-ecological zones. 


\section{Acknowledgement}

The author acknowledged the Ministry of Science and Technology, Govt. of the Peoples Republic of Bangladesh for providing financial support to conduct the study at Sher-e-Bangla Agricultural University.

\section{References}

Alandia, G., S.-E. Jacobsen, N.C. Kyvsgaard, B. Condori and F. Liu. 2016. Nitrogen sustains seed yield of quinoa under intermediate drought. J. Agron. Crop Sci. 202: 281291, doi: 10.1111/jac.12155.

Basra, S.M.A., S. Iqbal and I. Afzal. 2014. Evaluating the response of nitrogen application on growth, development and yield of quinoa genotypes. Intl. J. Agric. Biol. 16: 886-892.

Bazile, D., D. Bertero and C. Nieto. 2015. State of the Art Report on Quinoa around the World in 2013. Rome: Food and Agriculture Organization of the United Nations (FAO) \& CIRAD (Centre de coopération internationale en recherche agronomique pour le développement).

Bhargava, A., S. Sudhir and O. Deepak. 2006. Quinoa (Chenopodium quinoa Willd.). An Indian perspective. Inds. Crop Products. 23: 73-87.

Biswas, P.K. and Z.A. Tanni. 2020. Quinoa (Chenopodium quinoa Willd.) - A potential new crop in Bangladesh: Agronomic performance with sowing date. Bangladesh Agron. J. 23(1): 67-73.

Carlsson, R., P. Hanczakowski and T. Kaptur. 1984. The quality of the green fraction of leaf protein concentrate from Chenopodium quinoa Willd. grown at different levels of fertilizer nitrogen. Anim. Feed Sci. Technol. 11: 239-245.

Dost, M. 2015. Field evaluation results across locations and identification of suitable QUINOA varieties," in Wrap up Workshop of Regional Quinoa Project (TCP/RAB/3403-FAO) (Rome: Food and Agriculture Organization of the United Nations).

Erley, G.S.A., H.P. Kaul, M. Kruse and W. Aufhammer. 2005. Yield and nitrogen utilization efficiency of the pseudocereals amaranth, quinoa and buckwheat under differing nitrogen fertilization. Eur. J. Agron. 22: 95-100.

Fawy, H.A., M.A. Attia and R.H. Hagab. 2017. Effect of nitrogen fertilization and organic acids on grains productivity and biochemical contents of quinoa plant grown under soil conditions of Ras Sader-Sinai. Egyptian J. Desert Res. 67(1): 171-185.

Geren, H. 2015. Effects of different nitrogen levels on the grain yield and some yield components of quinoa (Chenopodium quinoa Willd.) under Mediterranean climatic conditions. Turk. J. Field Crops 20: 59-64.

Gomez, K.A. and A.A. Gomez. 1984. Statistical procedures for agricultural research 2nd Edn. IRRI, Los Banos, Languna, The Philippines, pp.62-74.

Gomaa, E.F. 2013. Effect of nitrogen, phosphorus and biofertilizers on quinoa plant (Chenopodium quinoa). J. Appl. Sci. Res. 9: 5210-5222.

Hirich, A. 2014. Effects of Deficit Irrigation using Treated Wastewater and Irrigation with Saline Water on Legumes, Corn and Quinoa Crops. Ph.D., thesis, Hassan II Institute of Agronomy and Veterinary Medicine, Morocco.

Hirich, A., R. Choukr-Allah and S.-E. Jacobsen. 2013. The combined effect of deficit irrigation by treated wastewater and organic amendment on quinoa (Chenopodium quinoa Willd.) productivity. Desalination Water Treat. 106, doi:10.1080/19443994.2013.777944.

Jacobsen, S.-E. and J.L. Christiansen. 2016. Some agronomic strategies for organic quinoa (Chenopodium quinoa Willd.). J. Agro. Crop Sci. 202(6): 01-10, doi:10.1111/jac.12174. 
Jacobsen, S.-E., I. Jørgensen and O. Stølen. 1994. Cultivation of quinoa (Chenopodium quinoa) under temperate climatic conditions in Denmark. J. Agric. Sci. 122: 47-52.

Kansomjet, P., P. Thobunluepop, S. Lertmongkol, E. Sarobol, P. Kaewsuwan, P. Junhaeng, N. Pipattanawong and M.T. Ivan. 2017. Response of physiological characteristics, seed yield and seed quality of quinoa under difference of nitrogen fertilizer management. Am. J. Plant Physiol. 12: 20-27.

Kaveeta, L., M. Nanakorn, S. Suwanwong and S. Tantiwiwat. 2009. Plant Physiology. Kasetsart University Press, Bangkok p.261.

Lavini, A., C. Pulvento, R. D'Andria, M. Riccardi, R. Choukr-Allah and O. Belhabib. 2014. Quinoa's potential in the Mediterranean region. J. Agron. Crop Sci. 200: 344-360. doi: 10.1111/jac.12069.

Oelke, E.A., D.H. Putnam, T.M. Teynor and E.S. Oplinger. 1992. Quinoa. Alternative Field Crops Manual. http://www.hort.pur due.edu/newcrop/afcm/quinoa.html.

Ramesh, K., K.B. Suneetha Devi, K.A. Gopinath and K. Praveen. 2019. Geographical adaptation of quinoa in India and agro techniques for higher productivity of quinoa. J. Pharma. Phytochem. 8(3): 2930-2932.

Rao, N.K. and M. Shahid. 2012. Quinoa - A promising new crop for the Arabian Peninsula. American-Eurasian J. Agric. Environ. Sci. 12(10): 1350-1355.

Repo-Carrasco, R., C. Espinoza and S.-E. Jacobsen. 2003. Nutritional value and use of the andean crops quinoa (Chenopodium quinoa) and Kañiwa (Chenopodium pallidicaule). Food Rev. Int. 19: 179-189. doi: 10.1081/FRI120018884.

Sadia, A. 2018. Influence of fertilizer levels on growth and yield of quinoa. MS thesis, Department of Agronomy, Sher-e-Bangla Agricultural University, Dhaka-1207, Bangladesh.

Schulte auf'm Erley, G., H.P. Kaul, M. Kruse and W. Aufhammer. 2005. Yield and nitrogen utilization efficiency of the pseudo cereals amaranth, quinoa and buckwheat under differing nitrogen fertilization. Eur. J. Agron. 22: 95-100.

Shams, A.S. 2011. Response of quinoa to nitrogen fertilizer rates under sandy soil conditions. Int J. Water Resour. Arid Environ. 1: 318-325.

Shams, A.S. 2012. Response of quinoa to nitrogen fertilizer rates under sandy soil conditions. Proceedings of the 13th International Agronomy Conference, September 9-10, 2012, Benha University, Egypt. pp.195-205.

Thanapornpoonpong, S. 2004. Effect of nitrogen fertilizer on nitrogen assimilation and seed quality of amaranth (Amaranthus spp.) and quinoa (Chenopodium quinoa Willd.). Ph.D. Thesis, Georg August University of Gottingen, Phayao, Thailand.

Weisany, W., Y. Raei, and K.H. Allahverdipoor. 2013. Role of some of mineral nutrients in biological nitrogen fixation. Bull. Env. Pharmacol. Life Sci. 2(4): 77-84. 